\title{
PENINGKATAN CINTA LINGKUNGAN DAN PEMBERDAYAAN MASYARAKAT PEDESAAN MELALUI PROGRAM PENGABDIAN MASYARAKAT
}

\section{INCREASED LOVE FOR THE ENVIRONMENT AND EMPOWERMENT OF RURAL COMMUNITIES THROUGH COMMUNITY SERVICE PROGRAMS}

\author{
RR Aliyyah ${ }^{1}$, RSP Fauziah ${ }^{2}$, dan N Asiyah ${ }^{1 a}$ \\ 1Program Studi Pendidikan Guru Sekolah Dasar, Fakultas Keguruan dan Ilmu Pendidikan, \\ Universitas Djuanda Bogor, Jl. Tol Ciawi No.1 Kotak Pos 35 Bogor 16720 \\ 2Program Studi Manajemen Pendidikan Islam, Fakultas Keguruan dan Ilmu Pendidikan, \\ Universitas Djuanda Bogor, Jl. Tol Ciawi No.1 Kotak Pos 35 Bogor 16720 \\ a Korespondensi: Nur Asiyah, Email: nurasiyah43@yahoo.com \\ (Diterima: 22-12-2016; Ditelaah: 22-12-2016; Disetujui: 02-02-2017)
}

\begin{abstract}
Kuliah Kerja Nyata (KKN) aims to make one of the form of the realization of Tri Dharma Perguruan Tinggi namely devotion, as an index of community development through works and tangible proof. Kuliah Kerja Nyata (KKN) is one of rural community empowerment activities designed by students who are able to deliver students into complete individuals with guidance of a lecturer, both in mastery of science, the ability to analyze the condition of the surrounding community, and provide solutions in overcoming various social problems, economic, health, education and politics in accordance with the field of science owned. Judging from the problems that occurred in the field then we make the program Kuliah Kerja Nyata (KKN) divided into four areas in which consists of education, religious, entrepreneurship, social environment health and infrastructure. Data were collected through multimethods such as interviews, observation, documentation studies, and audio-visual recording. The result of this real work lecture shows that it is a barometer of the ability of students to face and practice their knowledge in the field field that faces some problems that occur in the world of social life and also can increase the professionalism of competency capacity for graduates of the existing programs in the college.
\end{abstract}

Keywords: KKN, community empowerment, activity program.

\begin{abstract}
ABSTRAK
Kuliah Kerja Nyata (KKN) bertujuan menjadikan sesuatu bentuk perwujudan dari Tri Dharma Perguruan Tinggi yakni pengabdian, sebagai indeks pembangunan masyarakat melalui karya dan bukti nyata. Kuliah Kerja Nyata (KKN) adalah salah bentuk kerja yang nyata pada lingkungan masyarakat untuk pemberdayakan masyarakat pedesaan yang dirancang oleh mahasiswa yang mampu mengantarkan mahasiswa menjadi individu yang lengkap dengan bimbingan seorang dosen, baik dalam memanfaatkan ilmu, kemampuan menganalisis kondisi masyarakat sekitar, serta memberikan solusi dalam mengatasi berbagai permasalahan sosial, ekonomi, kesehatan, pendidikan maupun politik sesuai bidang keilmuan yang dimiliki. Dilihat dari problematika yang terjadi dilapangan maka kami membuat program Kuliah Kerja Nyata (KKN) terbagi kedalam empat bidang yang didalamnya terdiri dari bidang pendidikan, keagamaan, kewirausahaan, lingkungan sosial kesehatan dan infrastruktur. Data dikumpulkan melalui multimetode seperti wawancara, observasi, studi dokumentasi, dan perekaman audio visual. Hasil dari kuliah kerja nyata ini menunjukan bahwa merupakan barometer kemampuan para pelaksana mengabdikan dan mengamalkan ilmunya dalam dunia lapangan yang menghadapi beberapa masalah yang terjadi didunia kehidupan yang
\end{abstract}


berkelompok dan juga bisa meningkatkan profesionalisme kapasitas kompetensi bagi lulusan program yang ada di perguruan tinggi tersebut.

Kata Kunci: KKN, Pemberdayaan Masyarakat, Program Kegiatan.

Aliyyah RR, RSP Fauziah, dan N Asiyah. 2017. Peningkatan cinta lingkungan dan pemberdayaan masyarakat pedesaan melalui program pengabdian masyarakat. Qardhul Hasan: Media Pengabdian kepada Masyarakat 3(1): 46-61.

\section{PENDAHULUAN}

Pelaksanaan kegiatan secara berkelompok atau hidup berdampingan dengan masyarakat baru merupakan aktivitas yang rutin dilakukan seluruh mahasiswa keguruan dan sejajar dengan pendidikan atau pengajaran penelitian. Pengabdian kepada masyarakat merupakan bentuk usaha yang dilakukan secara bersama-sama atau kelompok atau bergotong royong dalam lembaga untuk membantu peningkatan taraf kehidupan masyarakat yang dibantu sesuai dengan misi yang diembannya.

Pengabdian masyarakat merupakan kegiatan yang wajib dilaksanakan oleh mahasiswa Fakultas Keguruan dan Ilmu Pendidikan.

Kegiatan pengabdian masyarakat sangat besar diharapkannya untuk membantu peningkatan taraf hidup masyarakat baik dari segi ekonomi, sosial dan pendidikan.

Dalam pengabdian masyarakat ada bermacam bagian yang di klasifikasikan yaitu bagian pendidikan, Agama, Lingkungan sosial, kesehatan, infrastruktur dan kewirausahaan. Dari setiap bidang, program direalisasikan selama pengabdian masyarakat berjalan. Kegiatan ini disusun agar setiap program terealisasikan dengan baik.

\section{MATERI DAN METODE}

Dasar hukum penyelenggaraan KKN FKIP, terdiri dari:

1. Undang-undang Nomor 20 tahun 2003 tentang Sistem Pendidikan Nasional;
2. PerturanPemerintah RI Nomor 19 Tahun 2005, tentangStandarNasionalPendidikan

3. Undang-undang RI Nomor 19 Tahun 2005, tentang Guru danDosen

4. PeraturanMenteriRiset, Teknologi, danPendidikanTinggiNomor 44 Tahun 2015, tentang Standar Nasional Pendidikan Tinggi

5. Keputusan Rektor Universitas Djuanda Nomor 16/2015 tentangkurikulum Program Studi Fakultas Keguruan dan Ilmu Pendidikan Universitas Djuanda.

\section{Pengumpulan Data}

Data yang dikumpulkan berupa data masyarakat sekolah dan warga RW 01, data ini merupakan sebagai sumber informasi untuk kami selaku mahasiswa KKN yang akan bermanfaat guna melihat sejauh mana kemampuan masyarakat dalam mengelola dirinya sendiri sehingga dikemudian hari dapat dirancang sebuah program yang berkelanjutan yang berbasis pada kemampuan masyarakat itu sendiri. Selain itu, data ini dapat dijadiakan bahan laporan akhir setelah kegiatan KKN berlangsung selama 40 hari di lapangan. Manfaat lain dari pengumpulan data ini bisa dijadikan bahan laporan universitas kepada badan pendidikan daerah sebagai salah satu masukan untuk nilai tambah kepada universitas kemudian data akan bermanfaat guna menyusun langkah dan strategi yang digunakan oleh masyarakat dalam melaksanakan program kegiatan sebagai tindak lanjut dari program yang mahasiswa laksanakan. 


\section{Survei Lokasi}

Survei lokasi dilaksanakan dengan melihat kondisi lingkungan di desa cipayung girang, survei lokasi ini sangat dibutuhkan mahasiswa untuk menggali potensi yang dimiliki oleh desa tersebut mulai dari segi kebersihan, kesehatan dan infrastruktur. Survei lokasi dilakukan guna mengetahui kekurangan apa saja yang ada di desa cipayung girang dan apa saja yang perlu di tingkatkan guna meniciptakan desa yang lebih baik dan produktif. Dilihat dari itu pun kami sebagai mahasiswa akan giat untuk melaksanakan berbagai kegiatan demi meningkatkan potensi yang ada sesuai dengan kondisi lingkungan yang ada di desa tersebut.

\section{HASIL DAN PEMBAHASAN}

\section{Hasil}

Dari berbagai gerakan yang dapat menghasilkan maka hasil Pengabdian Masyarakat kelompok kami yaitu sebagi berikut: 1) bidang pendidikan pendampingan siswa/i dengan berbagai kegiatan sesuai mata pelajaran a) mampu mendapatkan pengalaman menumpahkan ilmu di sekolah MI At-taufiq dan Paud Mentari b) mendapatkan arahan dalam mengajar c) dapat mengetahui berbagai karakter siswa/i di sekolah. 2) bidang kegamaan a) mengetahui budaya masyarakat dalam peningkatan rohani b) mengetahui keadaan mengenai fasilitas tempat beribadah yang kurang baik c) mendapatkan pengetahuan agama dengan metode tradisional 3) bidang lingkungan,kesehatan, dan infrastruktur a) mengetahui kurangnya kepedulian masyarakat terhadap sampah b) mengetahui ilmu cara mengolah sampah organis dan non organik c) mengetahui cara kerja penanganan masyarakat dengan dampingan POSYANDU d) mengetahui kurangnya penempatan sampah di sekitar lingkungan 4) bidang kewirausahaan yaitu a) mengetahui potensi penghasilan tanah setempat bisa diolah untuk meningkatkan perekonomian warga b) mengetahui akan cara pemanfaatan SDA di desa yang kelompok diami c) mengetahui tingkat kreatifitas warga ciletuh.

\section{Pembahasan}

\section{Bidang Lingkungan Sosial, kesehatan, dan Infrastruktur}

Dengan dilaksanakannya bermacam-macam kegiatan yang telah disusun dalam program ini yaitu khususnya mengenai bidang lingkungan sosial, kesehatan dan insfrastruktur sebagaimana tersusun pada tabel 1.

Tabel 1 Perencanaan program KKN Desa Cipayung Girang

\begin{tabular}{|c|c|c|}
\hline \multicolumn{3}{|c|}{$\begin{array}{l}\text { Divisi Lingkungan sosial, Kesehatan dan } \\
\text { Infrastruktur }\end{array}$} \\
\hline $\begin{array}{l}\text { Pengadaan } \\
\text { tong } \\
\text { sampah }\end{array}$ & $\begin{array}{l}\text { Menyadarkan } \\
\text { dan } \\
\text { membiasakan } \\
\text { kebersihan } \\
\text { lingkungan }\end{array}$ & $\begin{array}{l}\text { Masyarakat } \\
\text { sekitar }\end{array}$ \\
\hline $\begin{array}{l}\text { Penyuluhan } \\
\text { mengenai } \\
\text { pengolahan } \\
\text { sampah }\end{array}$ & $\begin{array}{l}\text { Untuk } \\
\text { memberikan } \\
\text { pemahaman } \\
\text { mengenai } \\
\text { pengolahan } \\
\text { sampah }\end{array}$ & IRT \\
\hline $\begin{array}{l}\text { Cek } \\
\text { kesehatan } \\
\text { untuk } \\
\text { BALITA }\end{array}$ & $\begin{array}{l}\text { Membantu } \\
\text { kegiatan } \\
\text { Posyandu } \\
\text { dalam } \\
\text { pelaksanaan } \\
\text { DDTK } \\
\text { (Deteksi Dini } \\
\text { Tumbuh } \\
\text { Kembang) }\end{array}$ & $\begin{array}{l}\text { BALITA, } \\
\text { Siswa/I } \\
\text { PAUD }\end{array}$ \\
\hline $\begin{array}{l}\text { Penyuluhan } \\
\text { mengenai } \\
\text { kesehatan } \\
\text { reproduksi } \\
\text { ibu }\end{array}$ & $\begin{array}{l}\text { Membantu } \\
\text { meningkatkan } \\
\text { kesehatan ibu }\end{array}$ & $\begin{array}{l}\text { Ibu-ibu } \\
\text { warga } \\
\text { setempat }\end{array}$ \\
\hline $\begin{array}{l}\text { Cek } \\
\text { kesehatan } \\
\text { untuk } \\
\text { LANSIA }\end{array}$ & $\begin{array}{l}\text { Membantu } \\
\text { masyarakat } \\
\text { pentingnya } \\
\text { menjaga } \\
\text { kesehatan }\end{array}$ & Lansia \\
\hline
\end{tabular}


Adapun tugas pelaksanaan program yang sudah tersusun yaitu dituliskan dengan tersusun sebagaimana tabel 2 .

Tabel 2 Pembagian tugas program pengabdian masyarakat Cipayung Girang

\begin{tabular}{lll}
\hline No & \multicolumn{1}{c}{ Kegiatan } & \multicolumn{2}{c}{ Minggu } \\
\cline { 2 - 3 } & & I II III IV V VI \\
\hline \multirow{3}{*}{1} & Divisi Lingkungan, sosial, kesehatan \\
dan infrastruktur & Cek \\
& Kesehatan \\
& Balita, dan \\
& Siswa/i \\
& PAUD \\
$2 \quad$ & Penyuluhan \\
& Pemilahan \\
& Sampah \\
3 & Kerja Bakti \\
4 & Penyuluhan \\
& Kesehatan \\
& dan Cek \\
& kesehatan \\
& LANSIA \\
5 & 17 Agustus \\
\hline
\end{tabular}

Kepedulian masyarakat terhadap kebersihan masih kurang terutama di lingkungan rumahnya masing-masing dan dalam masalah sampah.

Masalah puncak dikampung Ciletuh yaitu tumpukan sampah disembarang lahan tempat warga dan sampah yang berserakan disetiap jalan. Sehingga menjadikan lingkungan sekitar yang kurang indah dan membuat kondisi tidak nyaman. Kurangnya kesadaran warga akan kebersihan yang sederhana mengenai pembuangan sampah dapat memberi aroma yang tidak sedap dan partikel yang diadakan oleh pembakaran sampah sembarang tempat. Kemudian pembuangan sampah di saluran air / selokan daerah lingkungan sekitar Kp. Ciletuh RT.03/05 yang mengakibatkan kebanjiran dan pembendungan air nya.

Untuk membekali pengetahuan akan pentingnya sampah. Oleh sebab itulah, kami melakukan penyuluhan pemilahan jenis sampah yang dapat didaur ulang dan kotoran rumah tangga yang tidak dapat didaur ulang, demonstrasi pemilahan sampah organik dan non organik, serta demonstrasi pembuatan pupuk kompos, memberi asupan tambahan untuk anak-anak, dan cek tekanan darah bagi lansia.Tujuan dari kegiatan mengadakan acara tersebut untuk memberikan pengetahuan dan pembekalan tentang pemanfaatan sampah, serta pentingnya akan kesehatan dengan terhadap lingkungan sehingga terwujudnya lingkungan yang bersih dan sehat. Mengingat permasalahan sampah yang belum teratasi serta mengatasi rendahnya tingkat kepedulian akan kesehatan.

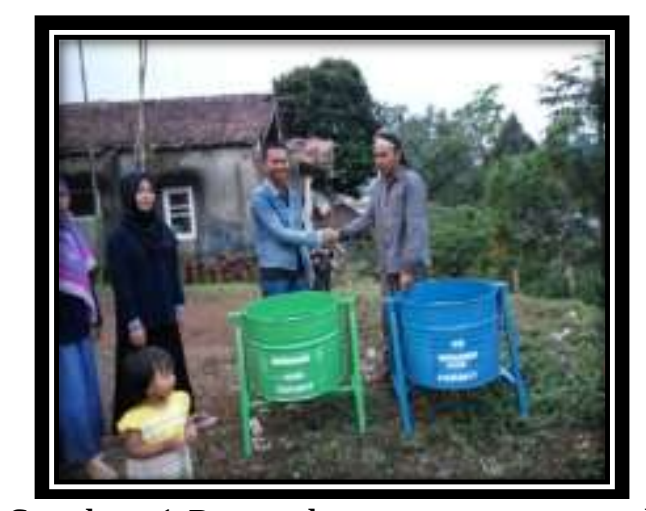

Gambar 1 Pengadaan tempat sampah

Pengadaan tong sampah di depan halaman PAUD MENTARI yang merupakan titik strategis warga untuk membuang sampah dan dihadiri oleh Bapak Ketua RT $05 / 01$. Keadaan tempat pembuangan akhir sampah warga sekitar yang tidak terkendali dengan baik sehingga sampah menumpuk dan menimbulkan bau tak sedap juga menjadi sarang penyakit.

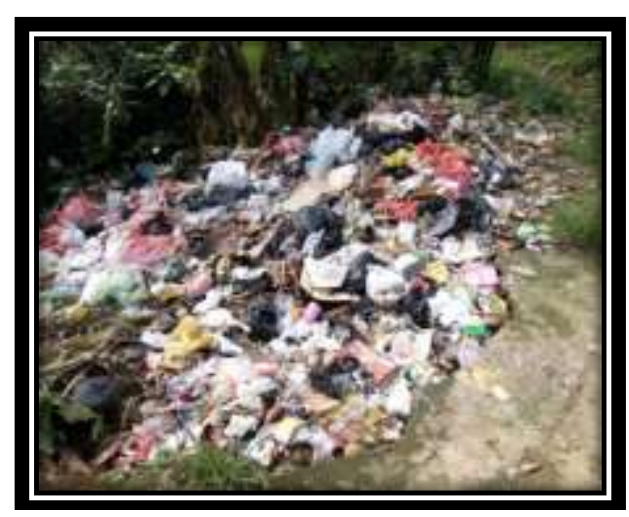

Gambar 2 Kondisi pembuangan sampah warga 


\section{Bidang Pendidikan}

Kegiatan yang diaplikasikan dilapangan yaitu mengecat dan menghias ruangan kelas sesuai dengan kepribadian anak. Tujuan nya yaitu untuk menciptakan ruangan kelas yang indah, edukatif dan nyaman sehingga dapat meningkatkan estetika kelas yang akan berpengaruh pada daya pengetahuan, imajinasi, kreativitas, dan konsentrasi anak dalam prose belajar, menghias Madrasah Ibtidaiyah, mengembangkan metode pembelajaran. Adapun kegiatan kita dari awal yaitu membersihkan Madrasah Ibtidaiyah, setelah itu pengecatan dinding Madrasah Ibtidaiyah, membuat jadwal piket dan membuat struktur organigram Menghias Madrasah Ibtidaiyah bertujuan Kegiatan menciptakan suasana yang bervariatif, rekreatif, dan edukatif serta nyaman. mengajar dengan menerapkan bermacam- macam gaya mengajar. seperti metode picture and picture ( pelajaran Akidah Akhlak), metode Kontekstual Learning ( Tema 1 benda - benda yang berada di sekitarku), SAINTIFIC (Tema 1 benda benda yang ada di sekitarku) menyanyi bersama dan lain - lain. Tujuan Kegiatan Membantu guru melakukan proses pembelajaran di dalam kelas dengan menggunakan metode picture dan picture, contecstual learning, SAINTIFIC, menyanyi bersama dan lain - lain. membantu proses pembelajaran sesuai dengan cara mengajar yang baik seperti permainan, menggambar dan menyanyi. Tujuan Kegiatan pendampingan tenaga pendidik dalam kegiatan pembelajaran yang menarik perhatian dan minat siswa PAUD. Dari bermacam-macam aktivitas yang sudah di rencanakan maka sebagaimana tabel 3

Tabel 3 Perencanaan Program KKN Desa Cipayung Girang

\begin{tabular}{|c|c|c|}
\hline \multicolumn{3}{|c|}{ Divisi Pendidikan } \\
\hline Menata ulang PAUD, Taman & Mencipatakn ligkungan belajar yang & Paud \\
\hline Baca, MI At-Taufiq & $\begin{array}{l}\text { baru agar tercipta rasa nyaman bagi } \\
\text { siswa }\end{array}$ & $\begin{array}{l}\text { Mentari/Taman } \\
\text { Baca }\end{array}$ \\
\hline Prakarya & $\begin{array}{l}\text { Membantu mengembangkan } \\
\text { kreatifitas peserta didik dari segi } \\
\text { afektif dan psikomotorik. }\end{array}$ & Siswa MI At-Taufiq \\
\hline $\begin{array}{l}\text { Pendampingan siswa dalam } \\
\text { PAUD dan MI dalam proses } \\
\text { belajar }\end{array}$ & $\begin{array}{l}\text { Membantu siswa dalam proses } \\
\text { pembelajaran di kelas }\end{array}$ & Siswa MI dan PAUD \\
\hline $\begin{array}{l}\text { Pemanfaatan Teknologi } \\
\text { dalam penerapan Pendidikan } \\
\text { Karakter }\end{array}$ & $\begin{array}{l}\text { Mengenalkan siswa pada teknologi, } \\
\text { mengenai manfaat dan dampaknya }\end{array}$ & Siswa MI \\
\hline Ektrakurikuler & $\begin{array}{l}\text { Membantu siswa menyalurkan minat } \\
\text { dan bakatnya melalui kegiatan } \\
\text { ektrakurikuler }\end{array}$ & Siswa MI \\
\hline Seminar Pendidikan & $\begin{array}{l}\text { Memberikan informasi kepada } \\
\text { pendidik dan orang tua siswa } \\
\text { mengenai pendidikan anak }\end{array}$ & $\begin{array}{l}\text { Guru dan } \\
\text { Murid }\end{array}$ \\
\hline
\end{tabular}

Tabel 3 merupakan penjabaran dari berbagai kegiatan yang akan dilakukan oleh mahasiswa KKN khusus nya di bidang pendidikan. Mulai dari kegiatan menata kembali ruang belajar PAUD MENTARI yang sebelumnya masih dalam keadaan kurang edukatif. Program yang kedua adalah memberikan pengetahuan dan memfasilitasi siswa untuk meningkatkan kreativitas khususnya dalam membuat berbagai kerajinan tangan. Ketiga program pendampingan pendidik dalam memberikan pengajaran yang lebih menarik. Program selanjutnya ialah menambah wawasan siswa mengenai pemanfaatan teknologi guna menunjang pembelajaran. Kemudian 
program ke-5 yaitu ekstrakurikuler sebagai bentuk kegiatan tambahan untuk siswa dalam mengembangkan potensi yang dimiliki. Dan program terakhir yang dilaksanakan dalam bidang pendidikan yaitu memberikan pembekalan pengetahuan kepada orang tua maupun tenaga pendidik mengenai metode mendidik anak dengan konsep yang diterapkan rasulullah.

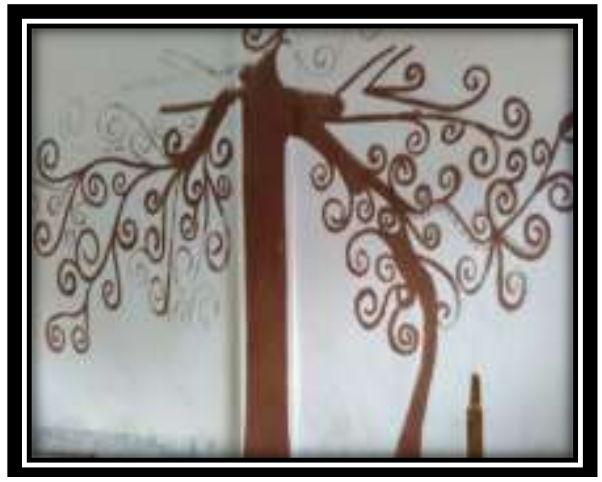

Gambar 3 Menata ulang ruang kelas MI Attaufiq
Gambar 3 merupakan hasil karya mahasiswa dengan menggunakan bahan dasar cat. Bertujuan untuk menciptakan ruang kelas yang lebih berwarna.

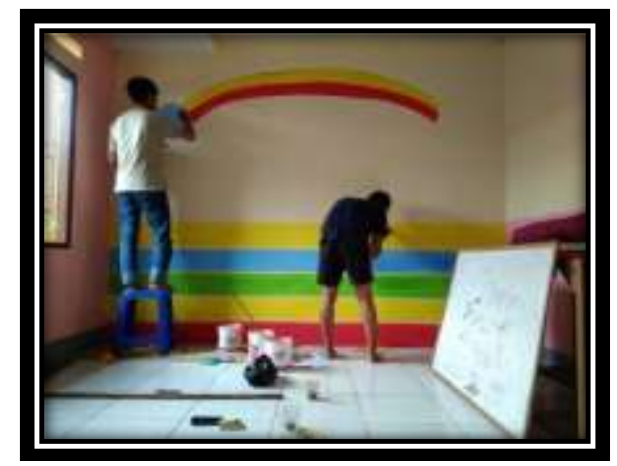

Gambar 4 Menata Ulang Ruang Kelas PAUD MENTARI

Adapun tugas diambang pelaksanaan kegiatan yang sudah terinci dengan baik yaitu dituliskan dengan tersusun sebagaimana tabel 4 .

Tabel 4 Tabel pembagian tugas program pengabdian masyarakat

\begin{tabular}{|c|c|c|c|c|c|c|}
\hline \multirow{2}{*}{ No } & \multirow{2}{*}{ Kegiatan } & \multicolumn{5}{|c|}{ Minggu } \\
\hline & & I II & III & IV & $\mathrm{V}$ & VI \\
\hline & Divisi Pendidikan & & & & & \\
\hline 1 & Menata ulang PAUD ,Taman Baca, MI At-Taufiq & & & & & \\
\hline 2 & Prakarya & & & & & \\
\hline 3 & $\begin{array}{l}\text { Pendampingan siswa dalam PAUD dan MI dalam proses } \\
\text { pembelajaran }\end{array}$ & & & & & \\
\hline 4 & Pemanfaatan Teknologi dalam Pendidikan Karakter & & & & & \\
\hline 5 & Ektrakurikuler & & & & & \\
\hline 6 & Seminar Pendiidkan & & & & & \\
\hline
\end{tabular}

\section{Bidang Keagamaan}

Program yang kami laksanakan antara lain mengajar menggunakan cara mengajar Bahasa Arab seperti memberikan kosa kata bahasa arab dan materi mengenai ilmu agama lainnseperti (Aqidah Akhlak, Fiqh, AlQur'an). Tujuan Kegiatan ialah mendampingi pendidik atau mudaris dalam proses pembelajaran dengan menerapkan cara mengajar Bahasa Arab dengan memberikan kosa kata bahasa arab dan pelajaran keagamaan lainnya seperti (Aqidah Akhlak, Fiqh, Al-Qur'an), membantu proses pembelajaran dengan berbagai metode menggambar, menyanyi, serta pemberian kosa kata dengan bahasa arab, tujuan Kegiatan ialah untuk membantu mudabbir dalam pelaksanaan proses pembelajaran dengan berbagai metode menggambar, menyanyi, serta pemberian kosa kata dengan bahasa arab. membimbing siswa-siswi untuk belajar menerapakan pengetahuan berbahasa arab dalam kehidupan seharihari.

Tujuan Kegiatan ialah untuk Membimbing peserta didik MI/SD mengenali bahasa arab dengan metode pemberian kosa kata dan membuat kolase agar mudah dipahami dan di mengerti, mengikuti pengajian rutin di 
mejlis ta'lim Karena dalam pengajian majelis ta'lim merupakan pesertanya hanya ibu-ibu, di dampingi oleh pimpinan majelis ta'lim dan seorang ustadz. Ketika berceramah seorang ustadznya tidak menggunakan microfon dan ditutup hijab yang mana terpisah dengan jama'ah, jadi kami hanya ikut berpartisipasi dalam pengajian majelis ta'lim setiap pertemuan-pertemuan yang ada. Dan kami pun hanya mendengarkan ceramah dari seorang ustadz sekaligus silaturrahim dengan jama'ah ibu-ibu, Yasinan sekaligus marhaba'an rutin bersama remaja desa sekitar ciletuh setiap kamis. Sebagai seorang yang beriman, kita dituntu untuk selalu melakukan refleksi dan perenungan terhadap apa yang telah kita perbuat. Keika seseorang terlanjur melakukan kesalahan, bersegeralah untuk kembali ke jalan yang benar dengan taubatan nasuha sehingga dia tidak akan membuat kesalahan lagi yang akan merugikan dirinya sendiri. Maka dari itu kita harus senantiasa memperbaiki diri. Termasuk juga manusia memiliki sifat lupa, seringkali menjadikan seseorang merasakan kenikmatan dan juga bisa sekaligus merupakan sebuah ujian. Seperti contoh Allah telah memberikan kita nikmat maupun rejeki tetapi kita lupa akan tugas sebagai seorang hamba dalam bersyukur, sehingga Allah tidak memberikan keberkahan terhadap apa yang diberikan oleh-Nya. Bisa dibayangkan ketika seorang tidak bisa melupakan kejadian yang tidak mengenakan maka ituakan menjadikan beban hidupnya. Lupa juga bisa jadi bencana, yaitu ketika penyakit lupa tersebut mengakibatkan kecerobohan dan kerusakan. Seringkali seorang hamba menjadikan lupa itu sebagai sesuatu kebiasaan yang pada akhirnya akan berakibat pada dirinya sendiri ataupun orang lain.

Tujuan Kegiatan ini ialah untuk Membiasakan membaca yasin setiap malam jum'at, manfaat dari kegiatan itu adalah membentuk budaya baru dikalangan remaja sehingga menjadikan generasi yang lebih Islami. Kajian untuk remaja desa cipayung girang dengan memberikan materi dakwah, materi ini disampaikan kepada remaja setempat dengan gaya penyampaian yang trendy masa kini agar menyesuaikan dengan psikologis remaja, dan mudah di pahami sesuai dengan perkembangan pemahaman nya. Tujuan Kegiatan ialah untuk Membuka pikiran serta menambah wawasan remaja desa cipayung girang serta memperat pertemuan antara remaja laki-laki dan remaja perempuan desa cipayung girang dengan mahasiswa KKN. Dalam melaksanakan berbagai aktivitas program yang telah direncanakan dalam kegiatan ini yaitu khususnya mengenai bidang keagaamaan sebagaimana tersusun dalam tabel 5.

Berdasarkan tabel 5 menerangkan bahwa dalam perencanaan program yang akan dilaksanakan terbagi kedalam 5 kegiatan dan memiliki sasaran kepada siswa-siswi PAUD, Madrasah Ibtidaiyah, Kaum ibu, serta remaja laki-laki dan perempuan.

Adapun tugas dalam pelaksanaan kegiatan yang tekah terperinci yaitu dituliskan dengan tersusun sebagaimana tabel 6 .

Tabel 5 Perencanaan Program KKN Desa Cipayung Girang

\begin{tabular}{|c|c|c|}
\hline \multicolumn{3}{|c|}{ Divisi Keagamaan } \\
\hline $\begin{array}{l}\text { Pendampingan belajar siswa } \\
\text { MI dan PAUD }\end{array}$ & $\begin{array}{l}\text { Membantu siswa dalam proses } \\
\text { pembelajaran di kelas }\end{array}$ & $\begin{array}{l}\text { Paud Mentari/MI } \\
\text { At-Taufiq }\end{array}$ \\
\hline $\begin{array}{l}\text { Taman Baca dan Bimbingan } \\
\text { Belajar }\end{array}$ & $\begin{array}{l}\text { Meberikan tambahan belajar pada } \\
\text { siswa. }\end{array}$ & Siswa MI \\
\hline $\begin{array}{l}\text { Mengikuti pengajian rutin } \\
\text { majlis ta'lim }\end{array}$ & $\begin{array}{l}\text { Menambah ilmu agama dengan } \\
\text { metode salaf }\end{array}$ & $\begin{array}{l}\text { Mahasiswi dan Ibu- } \\
\text { Ibu }\end{array}$ \\
\hline Yasinan Remaja & $\begin{array}{l}\text { Membiasakan remaja membaca } \\
\text { yasin berjama'ah }\end{array}$ & $\begin{array}{l}\text { Remaja } \\
\text { Ciletuh }\end{array}$ \\
\hline Kajian Remaja & $\begin{array}{l}\text { Memberikan informasi mengenai } \\
\text { ilmu agama }\end{array}$ & $\begin{array}{l}\text { Remaja } \\
\text { Ciletuh }\end{array}$ \\
\hline
\end{tabular}


Tabel 6 Pembagian tugas Program KKN Desa Cipayung Girang

\begin{tabular}{|c|c|c|c|c|c|c|}
\hline \multirow[t]{2}{*}{ No } & \multirow[t]{2}{*}{ Kegiatan } & \multicolumn{5}{|c|}{ Minggu } \\
\hline & & I II & III & IV & $\mathrm{V}$ & VI \\
\hline & Divisi Per & & & & & \\
\hline 1 & Pendampingan belajar siswa MI dan PAUD & & & & & \\
\hline 2 & Taman Baca dan Bimbingan Belajar & & & & & \\
\hline 3 & Mengikuti pengajian rutin majlis ta'lim & & & & & \\
\hline 4 & Yasinan Remaja & & & & & \\
\hline 5 & Kajian Remaja & & & & & \\
\hline
\end{tabular}

Adapun pembagian tugas dalam program terbagi kedalam tujuh minggu waktu pelaksanaan. Pada minggu pertama diadakan pendampingan mengajar yang dilakukan di PAUD dan MI. Minggu ke-dua, kami melakukan aktivitas di taman baca untuk membantu siswa atau masyarakat sekitar yang ingin belajar tambahan. Selanjutnya minggu ketiga mengikuti pengajian rutin yang ada di kalangan masyarakat agar lebih berbaur dengan warga sekitar.

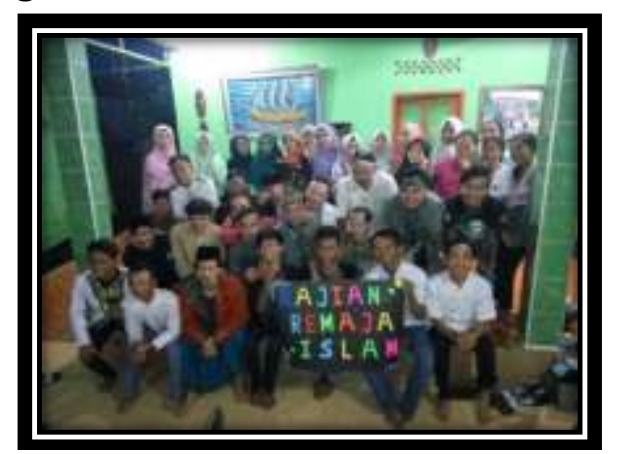

Gambar 5 Kajian Remaja Islam

Gambar ini menunjukan hasil dokumentasi dari kegiatan kajian remaja dengan narasumber Ustadz Alwi yang merupakan lulusan Universitas Djuanda.

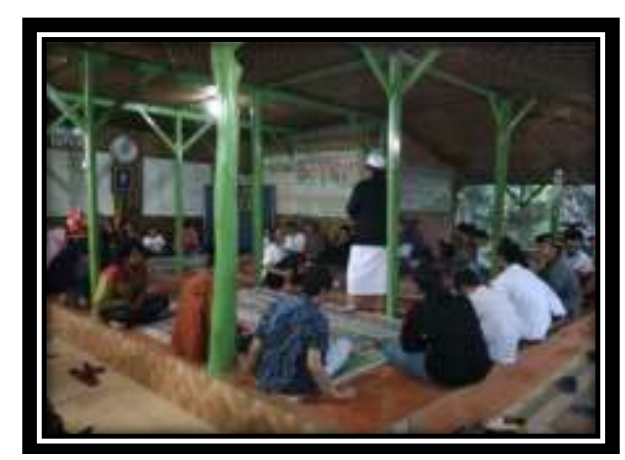

Gambar 6 Kegiatan Mejlis Ta'lim
Gambar diatas menunjukan aktivitas majlis ta'lim yang dilakukan di posko KKN bersama tokoh masyarakat setempat.

\section{Divisi Wirausaha}

Yang menjadi faktor penentu sebuah pengembangan masyarakat adalah kegiatan kewirausahaan. Dalam menjalankan usahanya, seseorang yang berwirausaha memerlukan berbagai sarana, misalnya, bahan alat maupun perlengkapan lainnya. Segala perlengkapan berwirausaha yang dibutuhkan tersebut semisalnya sumber daya atau bentuk produksi. Secara umum, yang dibutuhkan untuk menjalankan sebuah kegiatan usaha adalah sumber daya manusia, sumber daya alam, sumber daya modal, sumber daya manajerial dan teknologi. Sumber daya modal adalah daya keuangan, tidak ada satu pun kegiatan wirausaha yang tidak membutuhkan uang, dan sangat jarang sebuah usaha dibiayai oleh modal pemilik sepenuhnya. Berkaitan dengan ini, mencari asal muasal dana untuk memperlancar usaha dan mengelola asset finansial merupakan faktor utama bagi memperlancar usaha. Sumber daya manajerial pada dasarnya adalah bagian dari sumber manusia, tenaga kerja harus memiliki kemampuan mengelola dan mengorganisir seluruh daya lainnya sehingga tercapai tujuan perusahaannya. Teknologi merupakan jembatan bagi peningkatan efisiensi produksi. Memanfaatkan alat teknologi yang tepat guna akan mengoptimalkan kerja karyawan yang dimiliki, sehingga efisiensi produksi yang optimal dapat dicapai. Karyawan sebagai asset perusahaan yang berupa 
manusia yang dimiliki yaitu bagian yang memiliki posisi yang sangat penting dan diperlukan bagi perusahaan, karena karyawan adalah bagian yang aktif untuk mengolah sumber daya lainnya. Maka dari itu dibutuhkan orang-orang sebagai pengelola yang memiliki motivasi, keterampilan dan keahlian tinggi di bidangnya. Proses mengadaaan sumber daya manusia untuk dijadikan sebagai pengelola yang dilakukan dalam empat tahapan yaitu tahap pengrekrutan, seleksi, penempatan, dan pembinaan. Disamping itu ada Kegiatan kewirausahaan di kampung ciletuh dibentuk lapangan usaha oleh mahasiswa Djuanda meliputi; usaha masyarakat dalam memproduksi suatu barang atau jasa yang diperjual-belikan untuk memenuhi kebutuhan masyarakat. Secara keseluruhan program kerja bidang kewirausahaan dapat terealisasi dengan baik. Melalui program kegiatan kewirausahaan oleh KKN Universitas Djuanda memberikan informasi melalui kegiatan kewirausahaan untuk pemasaran produk-produk di Kp. Ciletuh, Desa Cipayung Girang. Seperti: Membuat Miniatur mobil, stick Pasawi, dan Es Djuloev. Adapun dari jasa yaitu membuat website dan akun untuk pemasaran produk agar proses pemasaran lebih diakui oleh masyarkat luas. Kesuksesan acara koordinator wirausaha sirespon baik oleh masyarakat. Namun terdapat juga beberapa faktor penghambat dalam pelakasanaan program kerja kewirausahaan diantaranya adalah ibu-ibu namun terkadang sulit untuk mengikuti kegiatan kewirausahaa, karena mereka sibuk dengan aktifitas kesaharian mereka masingmasing. Pengetahuan warga desa yang sangat minim tentang bagaimana pemberdayaan sumber daya alam yang ada di Kp. Ciletuh sebagai wadah industri.

Dalam melaksanakan berbagai aktivitas yang sudah dijadwalkan dalam kegiatan tersebut khususnya mengenai bidang wirausaha sebagaimana tersusun dalam tabel 7.

Tabel 7 Perencanaan program KKN Desa Cipayung Girang

\begin{tabular}{llll}
\hline \multicolumn{4}{c}{ Divisi Wirausaha } \\
\hline $\begin{array}{l}\text { Memberikan pelatihan dan } \\
\text { demosntrasi }\end{array}$ & $\begin{array}{l}\text { Memberiakan pelatihan mebuat produk } \\
\text { baru }\end{array}$ & $\begin{array}{l}\text { Ibu-ibu kampung } \\
\text { Ciletuh }\end{array}$ \\
$\begin{array}{l}\text { Demontrasi pembuatan } \\
\text { miniatur mobil-mobilan }\end{array}$ & $\begin{array}{l}\text { Memberikan informasi menegnai } \\
\text { pembuatan miniatur mobil-mobilan }\end{array}$ & \\
Mebuat stick Pasawi dan & $\begin{array}{l}\text { Membuat produk baru dengan } \\
\text { memanfaatkan SDA }\end{array}$ & Mahiswi dan \\
$\begin{array}{l}\text { Djuloev } \\
\text { Seminar Wirausaha }\end{array}$ & $\begin{array}{l}\text { Memberikan informasi tentang } \\
\text { berwirausaha dan pemasarannya Kampung }\end{array}$ & Ciletuh \\
\hline
\end{tabular}

Dari tabel yang penulis tuliskan atau gambarkan itu sesuai dengan kesepakatan bersama dengan individu yang lain. Secara pelaksanaanya pun kami melakukan bersama-sama agar biasa di kerjakan secara cepat, tepat, ringan dan memberi pengalaman. Banyak sekali manfaat dari pengerjaan secara gotong royong ini sebagaimana yang telah disebutkan tadi bahwa kerjaan akan serasa ringan.

Adapun tugas melaksanaan program yang sudah terealisasi yaitu dituliskan dengan terinci sebagaimana tabel 8.
Secara keselurahan program kewirausahaan dapat terealisasi dengan baik. Melalui program kewirausahaan mahasiswa KKN memberikan informasi pemasaran produk dan kemasan cantik. Kesuksesan program kewirausahaan didukung dengan respon masyarakat yang baik. Namun ada juga beberapa faktor penghambat dalam pelaksanaan program kerja ekonomi diantaranya adalah ibu-ibu namun terkadang sulit untuk turut serta dalam kegiatan kewirausahaan, karena mereka sibuk dengan aktifitas kesaharian mereka masing-masing. Pengetahuan 
masyarakat yang masih kurang tentang bagaimana mengelola dan memanfaatkan sumber daya alam yang ada di Kp. Ciletuh sebagai wadah industri.

Tabel 8 Pembagian tugas Program KKN Desa Cipayung Girang

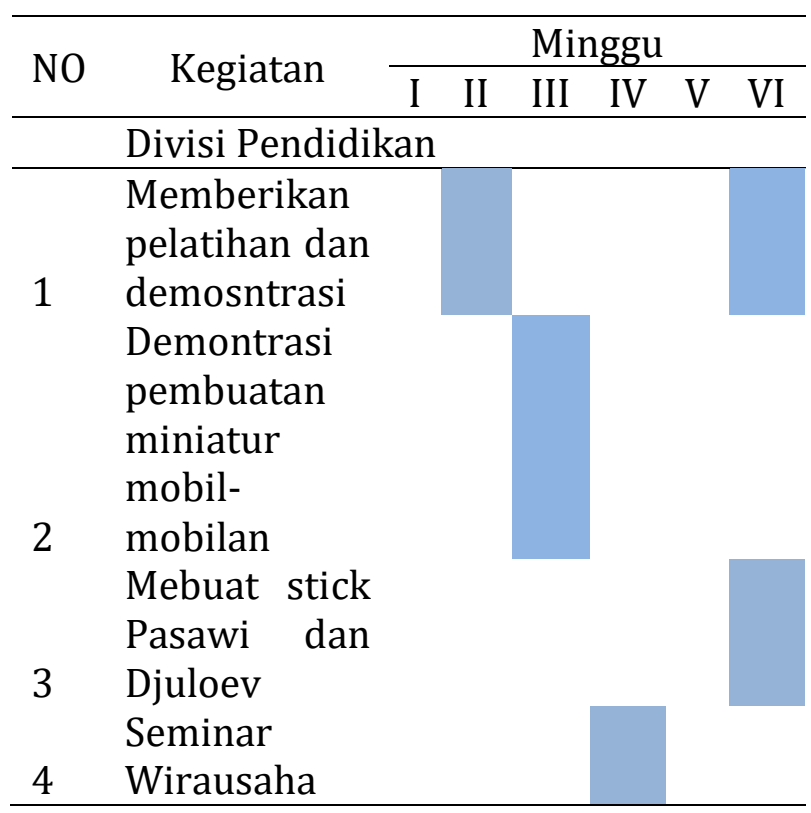

\section{Dengan} kewirausahaan program adalah peningkatan pengetahuan masyarakat dalam pengembanagan dan pemasaran produk, pengemasan produk yang telah berlabel dengan baik.

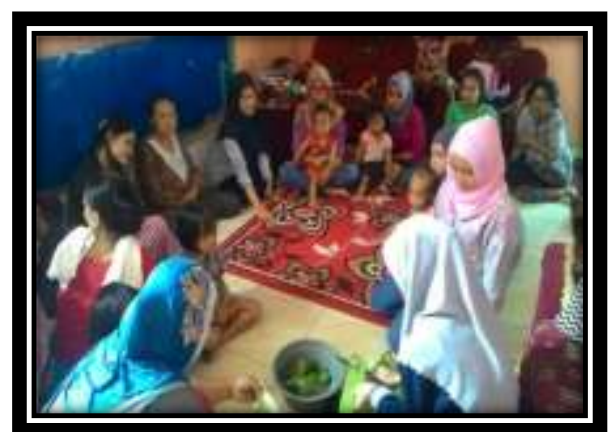

\section{Gambar $\quad 7 \quad$ Kegiatan Demonstrasi Pemanfaatan SDA}

Gambar dari bidang kewirausahaan sesuai dengan gambar yang ada yaitu dapat kami jelaskan bahwa kegiatan tersebut kami laksanakan di rumah warga cipayung girang yang mengundang ibu rumah tangga untuk meningkatkan pengetahuan warga dalam pengolahan minuman lidah buaya. Pembuatan minuman ini dilaksanakan pada siang hari ketika aktifitas warga tidak terlalu padat dan di waktu senggang.

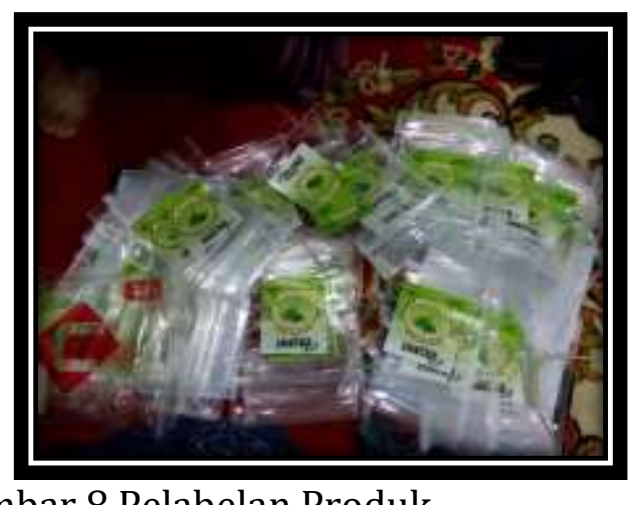

Gambar 8 Pelabelan Produk

Labelisasi ini merupakan bentuk strategi pemasaran untuk meningkatkan daya jual produk yang kami hasilkan dari kegiatan bidang wirausaha. Label ini sebagai salah satu ciri khas cipayung girang yang dibuatkan oleh mahasiswa KKN Djuanda.

\section{Analisis Situasi}

\section{Gambaran Geografi}

Desa Cipayung Girang merupakan salah satu desa dari sebelas desa yang berada di Kecamatan Megamendung Kabupaten Bogor yang letak administratifnya berbatasan dengan :

a. Sebelah Utara :Desa Gunung Geulis

b. Sebelah Timur :Desa Megamendung

c. Sebelah Selatan : Desa Kopo

d. Sebelah Barat :Desa Cipayung Datar

Desa Cipayung Girang terdiri dari dua dusun, yaitu Dusun Cinangka dan Dusun Cipayung, terdiri dari 4 (empat) Rukun Warga (RW) dan 24 (Dua puluh empat) Rukun Tetangga (RT). Desa Cipayung Girang merupakan desa yang terletak pada ketinggian permukaan laut $636 \mathrm{~m}\urcorner \neg 2$ dan berada di wilayah jalur pariwisata Puncak yang terbentang di tengahnya Jalan Raya Puncak yang menghubungkan Kota Jakarta dan Kota Bandung yang merupakan daerah strategis bagi perkembangan masyarakat sekitar karena sebagai jalur penghubung antara masyarakat Desa Megamendung dan Desa Kopo menuju pusat Kota Bogor.

Sebagian wilayah Cipayung Girang merupakan lahan pertanian dan pemukiman, sebagian juga sebagai sentra perdagangan 
karena letaknya berada disisi jalan protokol Jakarta - Bandung. Desa Cipayung Girang juga dialiri oleh dua aliran sungai, Sungai Ciesek dan Sungai Ciliwung yang merupakan Batas Administratif dengan Desa Kopo Kecamatan Cisarua.

a. Luas Wilayah

Luas Desa Cipayung Girang kurang lebih $775 \mathrm{Ha}$, terdiri dari:
1) Pemukiman : 271,04 Ha,
2) Pesawahan : 116,0 Ha,
3) Tegal / Ladang : 234,0 Ha,
4) Rawa/Lahan Basah: 116,03 Ha,
5) Kuburan : 8,0 Ha,
6) Prasarana Umum Lainnya: $29,93 \mathrm{Ha}$.

b. Situasi Cuaca / iklim

1) Ketinggian dari permukaan laut: 550$600 \mathrm{M}$

2) Suhu Udara rata-rata: $23-27 \mathrm{C}$

3) Curah Hujan :2500-4600 mm/tahun

c. Orbitasi Jarak tempuh ke Pusat Pemerintahan :

1) Ibu Kota Kecamatan $7 \mathrm{Km}$.

2) Ibu Kota Kabupaten : $30 \mathrm{Km}$.

3) Ibu Kota Provinsi : $118 \mathrm{Km}$.

4) Ibu Kota Negara : $73 \mathrm{Km}$.

d. Pemanfaatan Lahan di Desa Cipayung Girang dibagi beberapa bagian seperti:

1) Perumahan/Pemukimandan Pekarangan : 271,04 Ha

2) Sawah : 116,0 Ha

3) Tanah Darat/Keringan : 48,254 Ha

4) Pemakaman Umum: $8,0 \quad \mathrm{Ha}$

e. Batas Wilayah Desa Cipayung Girang berbatasan dengan :

1) Disebelah Utara :Desa Gunung Geulis, Kecamatan Sukaraja.

2) Disebelah Selatan :Desa Gadog, Kecamatan Megamendung dan Desa Kopo, Kecamatan Cisarua.

3) Disebelah Barat:Desa Pandansari dan Desa Cibanon, Kecamatan Sukaraja.

4) Disebelah Timur :Desa Cipayung Girang, Kecamatan Megamendung f. Iklim

Desa Cipayung Girang mempunyai suhu udara 23c sampai 27c dengan curah hujan sebesar 2500-4600 mm/tahun, dan jumlah curah hujan yang tinggi menjadikan Desa Cipayung, Kecamatan Megamendung, Kabupaten Bogor menjadi daerah pertanian.

\section{Gambaran Sosial dan Budaya}

a. Jumlah penduduk

Jumlah Penduduk Desa Cipayung Girang sampai saat ini, tercatat 9.079 Jiwa, yang terdiri dari Laki-laki 4.788 Jiwa, Perempuan 4.297 jiwa dengan jumlah Kepala Keluarga 2.520 KK

b. Mata Pencaharian

Mata pencaharian sebagai besar penduduk Desa Cipayung Girang adalah Buruh tani135 Jiwa , Buruh industri 107 Jiwa , dan PNS /ABRI 14 Jiwa, Pedagang 189 Jiwa, Buruh Bangunan 235 Jiwa, Pengusaha 25 Jiwa, Pensiunan 55 Jiwa, Petani 151 Jiwa, Supir angkutan 251 Jiwa, Lain-lain 125 Jiwa

c. Jumlah Penduduk Berdasarkan Kewarganegaraan
1) WNI Laki-laki : 4.788
2) WNI Perempuan : 4.297
3) WNA Laki-laki
4) WNA Perempuan

d. Jumlah Penduduk Berdasarkan Agama
1) Islam
: 9.047
2) Kristen
$: 35$
3) Khatolik :4
4) Hindu : :1
5) Budha
6) Khonghuchu : 3

e. Mata Pencaharian Penduduk Desa Cipayung Girang
1) Petani
: 151
2) Pedagang :189
3) PNS/ ABRI : 14
4) Pensiunan/Purnawirawan :55
5) Pengusaha
$: 25$
6) Buruh Bangunan
$: 235$ 
$\begin{array}{ll}\text { 7) Buruh Industri } & : 107 \\ \text { 8) Pengemudi Angkot } & : 251 \\ \text { 9) Buruh Tani } & : 135 \\ \text { 10)Lain-lain } & : 125\end{array}$

f. Jumlah Penduduk Berdasarkan Pendidikan

Strata pendidikan yang berada di Desa Sukamanah Kecamatan Megamendung Kabupaten Bogor memberikan data yang sangat bervariasi khususnya data jumlah penduduk menurut pendidikan yang secara umum merupakan gambaran indikator berhasil dan tidaknya program di bidang pendidikan dan ekonomi,berdasarkan data yang tercatat di Desa Sukamanah, bahwa penduduk dari segi pendidikan dengan klasifikasi sebagai berikut.

1) Tamat Pendidikan SD/Sederajat : 2.256

2) Tamat Pendidikan SLTP/Sederajat: 1.815

3) Tamat Pendidikan SLTA/Sederajat : 1.730

4) Perguruan Tinggi $: 300$

g. Prasarana Pendidikan
1) TK / PAUD
$: 8$
2) SD Negeri
$: 2$
3) MI / Sederajat
$: 2$
4) SLTP/Sederajat
$: 1$
5) SLTA / Sederajat
$: 1$
6) Tempat Kursus
$: 2$
7) TPA
8) Pondok Pesantren
$: 9$

h. Peribadatan

Sikap dan pola hidup masyarakat Desa Sukamanah merupakan cermin dan nilainilai kehidupan beragama.Sebagai masyarakat yang beragama, tentunya memerlukan sarana peribadatan sesuai dengan agama dan kepercayaannya masing-masing, antara lain:
1) Masjid
: 8 Unit
2) Musholla
: 27 Unit
3) Gereja Katolik
$: 1$
4) Vihara
$: 1$

i. Kesehatan

Kesehatan adalah salahsatu hal yang sangat penting dalam pembinaan bangsa guna mencapai cita-cita manusia seutuhnya yang sehat jasmani dan rohani. Kesehatan dapat mempengaruhi daya tahan tubuh manusia untuk tetap sehat. segar, dan kuat. Tentunya diimbangi dengan perawatan pemeriksaan kesehatan secara medis, atau ilmu kesehatan dan ilmu kedokteran. Upaya kami dengan Instansi terkait, dalam hal ini Puskesmas untuk pelayanan kesehatan masyarakat, antara lain :

1) Peningkatan Gizi Keluarga; Pemberian Makanan Tambahan (PMT) kepada Balita yang ada disetiap Posyandu, pemeriksaan kesehatan kepada Ibu hamil;

2) Pencegahan penyakit, Vaksinasi Filariasis (Kaki Gajah), imunisasi polio bagi Balita, pemberian Vitamin A;

3) Penyuluhan Kesehatan dan Penyakit, antara lain Demam Berdarah Dengue, Flu Burung, Chikungunya, dan sejenisnya;

4) Penanganan bagi Balita yang kekurangan Gizi dengan memberikan susu dan makanan yang bernutrisi;

5) Penyuluhan Kesehatan tentang bagaimana menjaga dan memelihara lingkungan dengan membersihkan rumah masing-masing dan lingkungan sekitarnya;

6) Pemanfaatan pekarangan dengan ditanami sayur mayur dan Tanaman Obat Keluarga (TOGA), Tabulapot dan Tabulakar;

Sebagai penunjang kegiatan tersebut di atas dibutuhkan sarana kesehatan yang tersedia di wilayah Desa Cipayung Girang antara lain:

1) Rumah sakit umum : -

2) Rumah sakit bersalin : :8-

3) Rumah sakit ibu dan anak :-

4) Puskesmas rawat inap : 1 
5) Puskesmas tanpa rawat inap: -

6) Puskesmas pembantu

7) Pos kesehatan Desa :-

8) Pondok Bersalin Desa

9) Praktik Dokter

10)Klinik Kesehatan

11)Posyandu

12)Dokter Pria

13)Dokter Wanita

14)Dokter Gigi

15)Bidan Desa

j. Ekonomi Masyarakat

Ekonomi masyarakat perlu ditingkatkan melalui upaya ekonomi produktif setiap individu.

Sarana

perekonomian/perdagangan di Desa Cipayung Girang, antara lain :

1) Jumlah Penginapan/hotel :16

2) Jumlah Restoran : 25

3) Jumlah Situs/Cagar Buda :-

4) Jumlah group kesenian :3

5) Jumlah UMKM

$: 3$

k. Kondisi Pemerintahan Desa

Susunan Organisasi dan tata cara Kerja Pemerintah Desa Cipayung Girang berpedoman kepada Peraturan Daerah Kabupaten Bogor, Tentang Desa, dan Peraturan Desa Cipayungt Girang, Tentang Susunan Organisasi dan Tata Kerja Pemerintahan Desa, maka keberadaan Perangkat Desa mengacu pada Peraturan tersebut dengan menggunakan Pola Maksimal, Organisasi dan Tata Kerja Pemerintah Desater diri dari Kepala Desa yang dibantu oleh Unsur Sekretariat, Unsur Wilayah dan Unsur Pelaksana Teknis.

Pemerintahan Desa Cipayung Girang sesuai dengan Peraturan dan Perundangundangan yang berlaku, Kepala Desa dibantu oleh Kepala Sekretariat (Sekretaris Desa), tiga ( 3 ) Kasie, tiga (3) Ka.Ur : yaitu, Kasie. Pemerintahan, Kasei. Pembangunan, Kasie. Kesejahteraan, Kepala Urusan Administrasi dan Staff, Kepala Urusan Keuangan dan Staff, Kepala Urusan Umum dan Staff, Unsur
Wilayah dikepalai oleh 2 (Dua) orang Kepala Dusun, dan Unsur Pelaksana Teknis terdiri dari Kasatgas Linmas, Mitra Cai, dan Pembantu Penghulu.

\section{Khalayak Sasaran}

\section{Bidang Kesehatan dan Infrastruktur}

1. Kurangnya perhatian kesadaran masyarakat akan kebersihan lingkungan terutama dalam pembuangan sampah

Tingkat kepedulian terhadap pentingnya kebersihan masih kurang terutama di lingkungan rumahnya masing-masing dan dalam masalah sampah. Kesehatan lingkungan pada hakekatnya adalah suatu kondisi atau keadaan lingkungan yang optimum, sehingga berpengaruh negatif terhadap terwujudnya status kesehatan yang optimum. Kegiatan ini diselenggarakan di Desa Cipayung Girang. Adapun kegiatan yang kami lakukan berupa penyuluhan pemilahan sampah organik dan non organik, demonstrasi pemilahan sampah organik dan non organik, serta demonstrasi pembuatan pupuk kompos.Tujuan dari kegiatan ini adalah memberikan pemahaman kepada warga mengenai pengolahan dan pemanfaatan sampah, agar tercipta lingkungan yang bersih dan sehat. Mengingat permasalahan sampah di Desa Cipayung Girang khususnya di RT 05/01 yang belum teratasi.Lokasi kegiatan penyuluhan sampah ini adalah di MI At-Taufiq, Kp. Para Ibu Rumah Tangga dapat membedakan dan memisahkan jenis sampah organik dan non organik, selain itu dapat mengetahui pemanfaatan sampah baik organik maupun non organik. Misalnya sampah plastik (non organik) dapat dimanfaatkan untuk pot bunga, dan sampah sayuran (organik) dapat dimanfaatkan untuk pupuk kompos.Adapun setelah kami mengadakan kegiatan penyuluhan, kemudian kami melakukan pengadaan tong sampah organik dan non organik bagi warga khususnya warga Kp. Ciletuh RT 05/01, agar dapat digunakan sebagai pembuangan sesuai dengan jenis sampah. 
2. Kurangnya pemberian makanan tambahan

Kesehatan adalah salah satu hal yang sangat penting dalam pembinaan bangsa guna mencapai cita-cita manusia seutuhnya yang sehat jasmani dan rohani. Kesehatan dapat mempengaruhi daya tahan tubuh manusia untuk tetap sehat. segar, dan kuat. Tentunya diimbangi dengan perawatan pemeriksaan kesehatan secara medis, atau ilmu kesehatan dan ilmu kedokteran. Salah satu upaya untuk meningkatkan kesehatan pada warga adalah dengan memperhatikan asupan gizi yang terdapat pada makanan yang biasa dikonsumsi oleh warga. Dan yang sangat perlu diperhatikan adalah asupan makanan yang diberikan kepada balita, karena akan mempengaruhi tumbuh kembangnya.

Tabel 9 Tabel Realisasi Program KKN Bidang Kesehatan

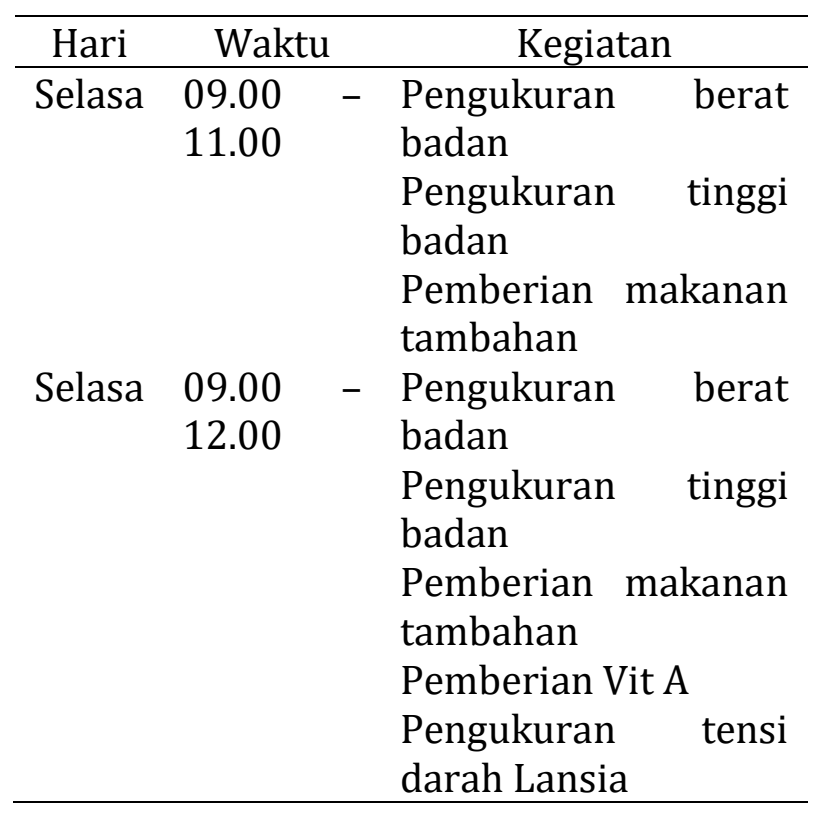

Maka dari itu kami melakukan kegiatan pemberian makanan tambahan untuk balita. Kegiatan ini bukan semata-mata hanya memberikan makanan tambahan saja, tetapi juga dengan memperhatikan kadar gizi yang dimiliki pada makanan yang akan diberikan. Kegiatan ini dilaksanakan di Posyandu Gelung Bandung, Kegiatan posyandu ini rutin dilakukan setiap satu bulan sekali per tanggal 18 berupa DDTK (Deteksi Dini Tumbuh Kembang). Adapun kami membantu kegiatan ini agar melengkapi kegatan tersebut dengan memberi makanan sehat untuk Bayi (0-1 th) Balita (1- 4 th) dan anak Usia Dini ( 4- 6 th).

Tabel program menerangkan kegiatan yang dilakukan oleh bidang kesehatan (Tabel 9) yaitu aktivitas yang berada di posyandu gelung bandung kemudian dilakukan kegiatan rutinitas posyandu dengan tambahan kegiatan pemberian Vitamin A dan pengecekan darah. Selain jumlah balita yang banyak dikampung tersebut termasuk kedalam kampong yang memiliki warga lansia yang cukup banyak dan perlu diperhatikan kesehatan nya maka dari itu kami mengadakan pengukuran tensi tekanan darah untuk lansia.

\section{Bidang Infrastruktur}

Melihat dari kondisi lingkungan Kp. Ciletuh Rt 05/01 Desa Cipayung Girang, salah satu permasalahran lingkungan yang ditemukan ialah tidak adanya tempat pembuangan sampah. Hal ini bisa saja menimbulkan berbagai permasalahan baik dibidang lingkungan maupun kesehatan, contohnya seperti banyak genangan air dari sampah yang berserakan hal tersebut dapat meningkatkan potensi untuk menjadi sarang nyamuk penyebab penyakit demam berdarah, Maka dari itu kami membuat program pengadaan tong sampah. Untuk merealisasikan program ini dimulai dengan: Pembelian Drum yang memiliki kapasitas Drum yaitu $155 \mathrm{Kg}$, Pemotongan Drum menjadi dua bagian dan dilanjutkan dengan proses pengelasan, Pembuatan kaki tempat sampah berbahan dasar besi Hollow melalui proses pengelasan, dan Pengecatan tong sampah beserta kaki tong sampah. Tujuan dari kegiatan adalah menyediakan tong sampah, agar warga memiliki wadah untuk pembuangan sampah baik sampah organik maupun non organik sehingga sampah dapat tertampung. Lokasi peletakan tong sampah ini tersebar di tiga titik di lingkungan Kp. Ciletuh RT 05/01, Desa Cipayung Girang. Sasaran kegiatan ini adalah warga Kp. Ciletuh RT 05/01 Biaya yang di keluarkan pada penyuluhan sampah adalah dari sumbangan donatur dan uang pribadi 
anggota kelompok III KKN FKIP UNIDA. Tersedianya tong sampah terdiri dari 3 pasang tong sampah organik dan non organik di Kp Ciletuh Rt 05/01. Adapun setelah melakukan kegiatan pengadaan tong sampah, kemudian warga Rt 05/01 bekerjasama dengan pihak ecovillage Desa Cipayung Girang untuk memproses sampah non organik. Sampah organik diolah untuk pembuatan pupuk kompos, adapun sampah non organik diolah kembali untuk dijadikan barang yang berguna.

\section{KESIMPULAN DAN IMPLIKASI}

\section{Kesimpulan}

Dari seluruh rangkaian aktivitas yang telah dilaksanakan, dapat kita tarik kesimpulan bahwa kegiatan yang telah dilaksanakan sudah berjalan baik dan bisa dikatakan sudah mencapai sasaran yaitu diantaranya tersedianya bak sampah di beberapa titik di desa cipayung girang, pemberian makanan tambahan untuk Balita, dan perilaku masyarakat terhadap pengelolaan sampah karena telah dilaksanakannya seminar tentang peduli akan lingkungan yang bekerjasama dengan Organisasi Taruna Kompos dan Ecovilage di desa cipayung girang yang menumbuhkan kesadaran masyarakat akan kebersihan lingkungan. Dari bidang kewirausahaan kegiatan dapat terlaksana dengan baik melihat antusias warga setempat ketika melakukan demonstrasi pembuatan es lidah buaya, dan puncak dari kegiatan wirausaha adalah minat beli pelanggan yang sangat tinggi terhadap produk yang kami hasilkan.

\section{Implikasi}

Hasil KKN yang telah dilaksanakan di Cipayung Girang, menunjukan bahwa dalam layanan akademik kampus Djuanda Bogor sangat berkonstribusi khususnya untuk para mahasiswa dan memberikan manfaat yang besar untuk masyarakat. Dalam KKN ini mewujudkan bahwa pengabdian kepada masysrakat itu merupakan bagian kepentingan untuk pelatihan Mahasiswa agar ilmu yang didapatkan dikampus dapat direalisasikan dalam kehidupan bermasyarakat. Dalam hal ini pun merupakan mutu layanan proses pembelajaran yang bisa mengukur kepuasan mahasiswa terhadap aspek mutu layanan proses pembelajaran yang sudah diprogramkan oleh pihak Kampus.

\section{UCAPAN TERIMA KASIH}

Ucapan terima kasih yang sebesar-besarnya kepada Badan Perencanaan Pembangunan Daerah (BAPPEDA) selaku lembaga teknis daerah di bidang penelitian dan perencanaan pembangunan daerah, Ibu $\mathrm{Hj}$. Srie Budi Sayekti selaku Kepala desa Cipayung Girang Kecamatan Megamendung beserta staf Desa.

\section{DAFTAR PUSTAKA}

Badan Standar Nasional Pendidikan (BSNP). 2007. Standar Pengelolaan Pendidikan Oleh Satuan Pendidikan Nonformal. Jakarta.

Departemen Pendidikan Nasional Direktorat Pendidikan dan Tenaga Kependidikan Pendidikan Nonformal. 2008. Standar Pengelolaan Pendidikan Oleh Satuan Pendidikan Nonformal. Pusat Perbukuan Departemen Pendidikan. Jakarta

Hukor.Kemdikbud. 2015. Peraturan Menteri Pendidikan dan Kebudayaan Republik Indonesia Nomor 23 Tahun 2015 tentang Penumbuhan Budi Pekerti (Permendikbud No. 23/2015). Diunduh pada 2 Oktober 2015 dari http://hukor.kemdikbud.go.id/asbodoku /media/peruu/Permendikbud_Tahun201 5Nomer023.pdf.(Oswari, 2006).

Nata, Abuddin. 2005. Tokoh-tokoh Pembaruan Pendidikan Islam di Indonesia. Raja Grafindo Persada, Jakarta. Sudin, Pengabdian masyarakat Digilib.uinsuka.ac.id,pdf. 